ArtikelPenelitian

\title{
Status Kerentanan Aedes Aegypti Vektor Demam Berdarah Dengue di Kota Padang
}

\author{
Kharisma Putra $D^{1}$, Hasmiwati ${ }^{2}$, Arni Amir $^{3}$
}

\begin{abstract}
Abstrak
Salah satu upaya mengurangi kasus DBD adalah pengendalian vektor Demam Berdarah Dengue (DBD) dengan larvisida temephos. Penggunaan temephos yang tidak sesuai aturan dapat menyebabkan penurunan kerentanan pada vektor DBD. Tujuan penelitian ini adalah menilai status kerentanan larva Aedes aegypti di tiga kecamatan di Kota Padang. Penelitian ini menggunakan post test only with control group design. Telur diambil dan dipelihara di laboratorium hingga mencapai larva instar III/IV. Uji kerentanan untuk temephos dilakukan berdasarkan standar WHO. Hasil penelitian menunjukkan pada Kecamatan Kuranji, kematian larva pada konsentrasi 0,005 mg/L sebesar $10 \%, 0,01 \mathrm{mg} / \mathrm{L}$ sebesar $45 \%$, 0,02 mg/L sebesar $86 \%$ dan konsentrasi $0,03 \mathrm{mg} / \mathrm{L}$ sebesar $100 \%$. Pada Kecamatan Koto Tangah, kematian larva pada konsentrasi 0,005 mg/L sebesar 24\%, 0,01 mg/L sebesar 48\%, 0,02 $\mathrm{mg} / \mathrm{L}$ sebesar $99 \%$, dan konsentrasi $0,03 \mathrm{mg} / \mathrm{L}$ sebesar $100 \%$. Pada Kecamatan Padang Timur pada konsentrasi $0,005 \mathrm{mg} / \mathrm{L}$ didapatkan kematian larva sebesar $12 \%$, pada $0,01 \mathrm{mg} / \mathrm{L}$ sebesar $43 \%$, pada $0,02 \mathrm{mg} / \mathrm{L}$ sebesar $99 \%$ dan konsentrasi $0,03 \mathrm{mg} / \mathrm{L}$ sebesar $100 \%$. Hasil uji One way-Anova adalah bermakna dengan nilai $\mathrm{p}<0,05$ pada ketiga kecamatan dan LC $_{99}$ sedikit diatas $0,02 \mathrm{mg} / \mathrm{L}$. Simpulan penelitian ini adalah status kerentanan Aedes aegypti terhadap temephos di tiga kecamatan berkisar antara rentan dan toleran, belum mencapai resisten sehingga temephos masih dapat digunakan dalam pengendalian vektor DBD, namun perlu dilakukan pemantauan secara terus menerus, sehingga resistensi vektor tidak terjadi.
\end{abstract}

Kata kunci: DBD, kerentanan, aedes aegypti, temephos

\begin{abstract}
A effort to reduce dengue cases is with dengue vector control with larvicide. The use of temephos that do not fit the rules can lead to decreased susceptibility to the vector of dengue. The objective of this study was to assess the susceptibility status of Aedes aegypti in three districts in Padang City. This study used a post-test only with control group design. The eggs were taken and maintained in the laboratory until it reach to the stage of $3^{\text {rd }} / 4^{\text {th }}$ instar larvae. This Susceptibility test of temephos is based on WHO standards. The results in District of Kuranji, larval mortality at a concentration of $0.005 \mathrm{mg} / \mathrm{L}$ were $10 \%, 0.01 \mathrm{mg} / \mathrm{L}$ were $45 \%, 0.02 \mathrm{mg} / \mathrm{L}$ were $86 \%$, and at a concentration of 0.03 $\mathrm{mg} / \mathrm{L}$ were $100 \%$. On Koto Tangah District, larval mortality at a concentration of $0.005 \mathrm{mg} / \mathrm{L}$ were $24 \%, 0.01 \mathrm{mg} / \mathrm{L}$ were $48 \%, 0.02 \mathrm{mg} / \mathrm{L}$ were $99 \%$, and at a concentration of $0.03 \mathrm{mg} / \mathrm{L}$ were $100 \%$. In the Padang Timur District, at a concentration of $0.005 \mathrm{mg} / \mathrm{L}$ obtained larval mortality by $12 \%$, at $0.01 \mathrm{mg} / \mathrm{L}$ were $43 \%$, to $0.02 \mathrm{mg} / \mathrm{L}$ were $99 \%$, and at $0.03 \mathrm{mg} / \mathrm{L}$ were $100 \%$, The test results One-way ANOVA was significant with a $p$ value $<0.05$ in the three districts and LC 99 slightly above $0.02 \mathrm{mg} / \mathrm{L}$. The conclusion of this study is the susceptibility status of Aedes aegypti to temephos in three districts ranged between susceptible and tolerant, yet still achieve temephos resistant so can be used in vector control of dengue, but it needs to be evaluated continuously, so the vector resistance does not occur.
\end{abstract}

Keywords: DHF, Susceptibility, Aedes aegypti, Temephos

Affiliasi penulis: 1. Prodi Profesi Dokter FK Unand (Fakultas Kedokteran Universitas Andalas Padang), 2. Bagian Parasitologi FK Unand, 3.Bagian Biologi FK Unand
Korespondensi: Kharisma Putra D, Email: kharismapd@yahoo.com Telp: 085766413186 


\section{PENDAHULUAN}

Demam Berdarah Dengue (DBD) merupakan penyakit yang disebabkan oleh virus dan ditularkan melalui perantara nyamuk Aedes aegypti dan Aedes

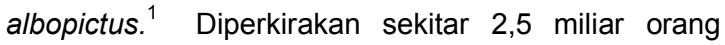
dalam 100 negara yang berbeda hidup dalam risiko yang tinggi. Setiap tahunnya diperkirakan terjadi sekitar lima puluh juta kasus infeksi DBD baru dengan angka kematian di atas 20.000 jiwa. $^{2}$

Tujuh puluh persen dari seluruh populasi dunia yang berisiko terhadap DBD tinggal di area Asia Tenggara dan wilayah Pasifik Barat. Kejadian epidemis menjadi masalah besar di beberapa negara berikut; Indonesia, Myanmar, Sri Lanka, Thailand, dan Timor Leste. Hal ini terjadi karena wilayah negara tersebut berada pada zona equator dan wilayah angin muson tropis, dimana Ae. aegypti berkembang cepat. ${ }^{1}$

World Health Organization (WHO) menetapkan Indonesia sebagai negara dengan kasus DBD tertinggi di Asia Tenggara. ${ }^{3}$ Perkembangan DBD di Indonesia sangat cepat, terhitung pada tahun 2009 sudah berkembang dari 2 provinsi menjadi 32 provinsi dan 382 kab/kota yang terjangkit.,

Incidence rate $\mathrm{DBD}$ di provinsi Sumatera Barat mencapai 63,23 per 100.000 penduduk dengan CFR $28,71 \%$. Sebagian besar kabupaten/kota di Sumatera Barat adalah daerah endemis DBD, termasuk Kota Padang. ${ }^{5}$

DBD adalah suatu penyakit infeksi virus dan hingga saat ini belum ditemukan vaksinnya, selain itu virus merupakan suatu mikroorganisme yang hanya dapat dikendalikan dengan mengendalikan nyamuk vektor dari virus DBD ini. Berdasarkan hal di atas, untuk mengantisipasi terjadinya penyebaran kasus harus dilakukan pengendalian terhadap vektor virus DBD, yaitu nyamuk Ae. aegypti dan Ae. albopictus. ${ }^{6,7}$

Di Indonesia telah dilakukan berbagai program dalam mengendalikan vektor $\mathrm{DBD}$, salah satunya adalah program abatisasi dengan temephos untuk mengendalikan larva vektor DBD yang juga telah berjalan selaman 30 tahun. $^{3,8,11}$ Walaupun usaha untuk mencegah DBD telah dilakukan, masih terjadi peningkatan kasus DBD setiap tahunnya. Selain karena adanya sifat penularan virus DBD secara transovarian, hal ini juga dipengaruhi oleh terjadinya perubahan dan penyebaran resistensi vektor DBD terhadap insektisida. ${ }^{7,9}$

Sudah banyak penelitian mengenai status kerentanan terhadap temephos dilakukan baik didalam maupun diluar negeri dan menunjukkan hasil status kerentanan beragam, seperti di Kota Sukabumi dengan hasil rentan dan Kota Banjar dengan hasil toleran. ${ }^{8,10}$

Mengingat temephos yang telah digunakan lebih dari 30 tahun sebagai program pengendalian vektor penular DBD termasuk di Kota Padang, ${ }^{11}$ maka perlu dilakukan evaluasi dengan menentukan status kerentanan larva Ae. aegypti di Kota Padang.

\section{METODE}

Penelitian ini adalah studi eksperimental laboratorium dengan rancangan post test only with control group design yaitu sebuah rancangan percobaan yang yang terdiri dari dua kelompok, yaitu kelompok kontrol dan kelompok eksperimen.

Penelitian dilakukan menggunakan 4 konsentrasi, yaitu $0,005 \mathrm{mg} / \mathrm{L}, 0,01 \mathrm{mg} / \mathrm{L}, 0,02 \mathrm{mg} / \mathrm{L}$, dan 1 diantaranya harus memberikan kematian 100\% pada larva uji, yaitu $0,03 \mathrm{mg} / \mathrm{L}$. Setiap konsentrasi diperlakukan 4 kali pengulangan. ${ }^{12}$

Sampel pada penelitian ini adalah larva instar III dan IV nyamuk Ae. aegypti yang didapatkan dengan koleksi telur dengan menggunakan perangkap nyamuk (ovitrap). Selanjutnya telur dibiakkan di laboratorium Parasitologi Fakultas Kedokteran Universitas Andalas hingga mencapai kriteria sampel dan dilakukan identifikasi untuk memastikan larva yang digunakan memang larva Ae. aegypti.

Besar sampel dalam penelitian ini adalah 20 ekor larva Ae. aegypti instar III/IV pada setiap konsentrasi uji dan kontrol dan dilakukan pengulangan sebanyak 4 kali untuk mengurangi kesalahan. ${ }^{12}$ Total larva yang dibutuhkan adalah 400 larva pada setiap kecamatan, dan 1200 larva untuk 3 kecamatan.

Kematian pada kelompok kontrol antara 5\% $20 \%$ maka harus dilakukan koreksi menggunakan formula Abbot, tetapi .jika kematian larva pada kelompok kontrol $>20 \%$, maka seluruh pelaksanaan 
penelitian dinyatakan gagal dan harus dilakukan penelitian ulang.$^{13}$

Secara deskriptif status kerentanan didapatkan melalui pengolahan data dengan membandingkan jumlah larva uji yang mati dibagi dengan jumlah seluruh larva uji dikali $100 \%$ pada dosis diagnostik yang ditetapkan WHO $(0,02 \mathrm{mg} / \mathrm{L}) .^{12,13}$

Data diuji menggunakan uji statistik One way ANOVA, kemudian selanjutnya dilakukan pengukuran menggunakan program Probit Analysis untuk menentukan LC99 24 jam. Jika didapatkan nilai LC $_{99}>$ $0,02 \mathrm{mg} / \mathrm{L}$ maka telah terjadi penurunan kerentanan pada larva uji. 8,13

\section{HASIL}

Larva diambil dari tiga kecamatan yang berbeda, yaitu Kecamatan Kuranji pada Kelurahan Korong Gadang, Kecamatan Koto Tangah pada Kelurahan Lubuk Minturun, dan Kecamatan Padang Timur pada Kelurahan Jati. Dari Penelitian yang dilakukan didapatkan hasil berikut:

Tabel 1. Jumlah kematian larva Kecamatan Kuranji

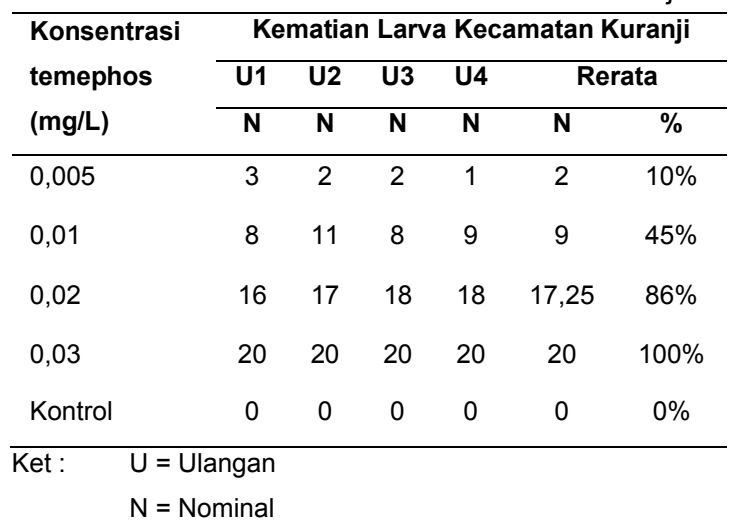

Berdasarkan Tabel 1 didapatkan bahwa jumlah kematian larva uji berbanding lurus dengan peningkatan konsentrasi. Pada konsentrasi diagnostik yang digunakan oleh WHO (0,02 mg/L) pada Kecamatan Kuranji didapatkan hasil kematian rerata17,25 dari 20 larva uji (86\%).

Tabel 2 memaparkan jumlah kematian larva uji pada Kecamatan Koto Tangah. Kematian larva uji pada dosis diagnostik di Kecamatan Koto Tangah menunjukkan hasil rata rata 19,75 dari 20 larva uji (99\%).
Tabel 2. Jumlah kematian larva Kecamatan Koto Tangah

\begin{tabular}{|c|c|c|c|c|c|c|}
\hline \multirow{3}{*}{$\begin{array}{l}\text { Konsentrasi } \\
\text { temephos } \\
(\mathrm{mg} / \mathrm{L})\end{array}$} & \multicolumn{6}{|c|}{$\begin{array}{c}\text { Kematian Larva Kecamatan Koto } \\
\text { Tangah }\end{array}$} \\
\hline & \multirow{2}{*}{$\begin{array}{l}\mathrm{U1} \\
\mathrm{N}\end{array}$} & \multirow{2}{*}{$\begin{array}{l}\text { U2 } \\
\mathbf{N}\end{array}$} & \multirow{2}{*}{$\begin{array}{c}\text { U3 } \\
\mathbf{N}\end{array}$} & \multirow{2}{*}{$\begin{array}{c}44 \\
\mathrm{~N}\end{array}$} & \multicolumn{2}{|c|}{ Rerata } \\
\hline & & & & & $\mathbf{N}$ & $\%$ \\
\hline 0,005 & 6 & 5 & 4 & 4 & 4,75 & $24 \%$ \\
\hline 0,01 & 10 & 10 & 9 & 9 & 9,5 & $48 \%$ \\
\hline 0,02 & 20 & 20 & 19 & 20 & 19,75 & $99 \%$ \\
\hline 0,03 & 20 & 20 & 20 & 20 & 20 & $100 \%$ \\
\hline Kontrol & 0 & 0 & 0 & 0 & 0 & $0 \%$ \\
\hline $\begin{array}{l}\mathrm{U}= \\
\mathrm{N}=\end{array}$ & & & & & & \\
\hline
\end{tabular}

Pada Tabel 3 dapat dilihat bahwa jumlah kematian larva pada konsentrasi diagnostik WHO pada Kecamatan Padang Timur sama dengan Kecamatan Koto Tangah, yaitu rerata 19,75 dari 20 jentik (99\%). Dari ketiga kecamatan didapatkan bahwa pada dosis $0,03 \mathrm{mg} / \mathrm{L}$ memberikan kematian total pada seluruh larva.

Tabel 3. Jumlah kematian larva Kecamatan Padang Timur

\begin{tabular}{lcccccc}
\hline \multirow{2}{*}{$\begin{array}{l}\text { Konsentrasi } \\
\text { temephos }\end{array}$} & \multicolumn{6}{c}{ Kematian Larva Kecamatan Padang } \\
(mg/L) & \multicolumn{6}{c}{ Timur } \\
\cline { 2 - 7 } & U1 & U2 & U3 & U4 & \multicolumn{2}{c}{ Rerata } \\
\cline { 2 - 7 } & $\mathbf{N}$ & $\mathbf{N}$ & $\mathbf{N}$ & $\mathbf{N}$ & $\mathbf{N}$ & $\%$ \\
\hline 0,005 & 3 & 3 & 1 & 2 & 2,3 & $12 \%$ \\
0,01 & 9 & 10 & 8 & 8 & 8,75 & $43 \%$ \\
0,02 & 20 & 20 & 19 & 20 & 19,75 & $99 \%$ \\
0,03 & 20 & 20 & 20 & 20 & 20 & $100 \%$ \\
Kontrol & 0 & 0 & 0 & 0 & 0 & $0 \%$ \\
\hline Ket : & $\mathbf{U}=$ Ulangan & & & &
\end{tabular}

WHO yang dikutip oleh Ridha dan Nisa (2011), membagi status kerentanan menjadi tiga kategori, yaitu resisten apabila kematian kurang dari $80 \%$, toleran apabila 80-97 \% dan rentan apabila $98-100 \%{ }^{8}$

Pada Tabel 4 dapat dilihat bahwa pada larva pada Kecamatan Kuranji tergolong kedalam kategori toleran, sedangkan larva pada Kecamatan Koto Tangah dan Padang Timur masih tergolong dalam kategori rentan terhadap larvisida temephos 
Tabel 4. Status kerentanan

\begin{tabular}{lccc}
\hline \multirow{2}{*}{$\begin{array}{c}\text { Lokasi } \\
\text { Penelitian }\end{array}$} & \multicolumn{2}{c}{$\begin{array}{c}\text { Rerata Kematian Larva } \\
\text { pada dosis diagnostik }\end{array}$} & $\begin{array}{c}\text { Status } \\
\text { Kerentanan }\end{array}$ \\
\cline { 2 - 3 } & $\mathbf{N}$ & $\%$ & \\
\hline $\begin{array}{l}\text { Kuranji } \\
\text { Koto }\end{array}$ & 17,25 & $86 \%$ & Toleran \\
$\begin{array}{l}\text { Tangah } \\
\text { Padang }\end{array}$ & 19,75 & $99 \%$ & Rentan \\
Timur & 19,75 & $99 \%$ & Rentan \\
\hline
\end{tabular}

Tabel 5. Analisis One Way ANOVA

\begin{tabular}{lcc}
\hline Lokasi Penelitian & Status Kerentanan & Nilai $\mathbf{p}$ \\
\hline Kec. Kuranji & Toleran & $<0,001$ \\
Kec. Koto Tangah & Rentan & $<0,001$ \\
Kec. Padang Timur & Rentan & $<0,001$ \\
\hline
\end{tabular}

Berdasarkan analisis One way-ANOVA, diperoleh informasi bahwa di ketiga kecamatan tersebut pemberian temephos masih berpengaruh terhadap kematian larva Ae. aegypti $(p<0,05)$. Dilanjutkan dengan analisis probit untuk mengetahui Lethal Concentration.

Tabel 6. Hasil analisis probit LC rerata

\begin{tabular}{lll}
\hline Lokasi & $\mathbf{L C}_{50}(\mathbf{m g} / \mathbf{L})$ & $\mathbf{L C}_{99}(\mathbf{m g} / \mathbf{L})$ \\
\hline Kuranji & 0,012 & 0,027 \\
Koto Tangah & 0,0095 & 0,022 \\
Padang Timur & 0,01 & 0,021 \\
\hline
\end{tabular}

Berdasarkan hasil analisis dengan menggunakan Probit Analysis Program didapatkan hasil yang beragam dari $\mathrm{LC}_{50}$ dan $\mathrm{LC}_{99}$ pada setiap kecamatan.Pada Tabel 5didapatkan rata-rata LC $_{99}$ pada ketiga kecamatan telah melebihi $0,02 \mathrm{mg} / \mathrm{L}$, yang berarti telah terjadi penurunan kerentanan larva pada ketiga kecamatan.

\section{PEMBAHASAN}

Berdasarkan penelitian yang telah dilakukan, maka air yang digunakan sebagai kontrol negatif tidak memberikan efek apapun terhadap larva uji, berarti air yang digunakan dalam penelitian ini terbebas dari kontaminasi zat organik dan senyawa klorin. Hal ini dibuktikan dengan hasil percobaan bahwa tidak ditemukan larva yang mati pada kelompok kontrol. ${ }^{12}$
Pada penelitian ini didapatkan hasil yang beragam, dimana pada Kecamatan Kuranji didapatkan hasil jentik yang telah mengalami penurunan kerentanan terhadap temephos (toleran), sedangkan pada Kecamatan Koto Tangah dan Padang Timur didapatkan jentik yang masih rentan terhadap temephos, artinya penggunaan larvisida temephos masih dapat menjadi pilihan dalam pengendalian larva pada daerah tersebut.

Hasil Toleran pada Kuranji serupa dengan penelitian didaerah lain di Indonesia seperti di Banjar, Kalimantan Selatan, dan Kota Surabaya, dimana didapatkan hasil toleran pada status kerentanan larva Ae. aegypti terhadap temephos. ${ }^{8,14}$ Penurunan status kerentanan larva terhadap temephos juga ditemukan pada negara lain seperti Thailand dan Brazil, dengan hasil toleran bahkan resisten terhadap larvisida temephos. ${ }^{15,16}$

Kesamaan hasil ini kemungkinan besar disebabkan oleh perilaku pengguna insektisida yang tidak sesuai dengan ketentuan. Penggunaan insektisida atau larvisida dalam mengendalikan vektor DBD secara kimiawi seperti pisau bermata dua, jika digunakan sesuai dengan ketentuan akan menguntungkan, tetapi di sisi lain dapat merugikan jika dipergunakan tidak sesuai aturan. Tindakan yang lazim dilakukan agar mendapatkan hasil yang lebih biasanya dengan meningkatkan frekuensi dan dosis penggunaan, maka kondisi ini akan mempercepat kejadian resistensi. ${ }^{3}$

'Sesuai dengan ketentuan pemerintah, larvisida yang digunakan dalam pengendalian larva memakai Abate sand granule dengan takaran 1 gram untuk 10 liter air. Abate dapat bertahan dalam tempat penampungan air hingga 3 bulan dan perlu diperhatikan saat penggantian air hendaknya jangan menyikat bagian dalam dinding tempat penampungan air tersebut. $^{8}$

Hasil yang sama pada Kecamatan Padang Timur dan Koto Tangah ditemukan pada penelitian lain yaitu di Kota Sukabumi yang dilakukan oleh Fuadzy et al (2015), dimana status kerentanan larva terhadap temephos masih dalam golongan rentan. ${ }^{10}$ 
Hasil analisis probit data kematian larva pada ketiga lokasi uji mendapatkan hasil lethal concentration $99 \%>0,02 \mathrm{mg} / \mathrm{L}$, yang berarti walaupun masih ada kecamatan yang tergolong masih rentan, sedikit banyaknya telah terjadi proses penurunan kerentanan. Hal ditandai dengan masih terdapat larva yang masih hidup pada dosis diagnostik $(0,02 \mathrm{mg} / \mathrm{L}){ }^{8}$

Resistensi pada larva terjadi melalui beberapa mekanisme, yaitu resistensi metabolik, resistensi situs target, penurunan penetrasi dan resistensi perilaku. ${ }^{18,19}$ Pada larvisida temephos yang merupakan golongan organofosfat, salah satu mekanisme yang terjadi adalah resistensi metabolik, yaitu terjadi peningkatan pembentukan enzim esterase yang dapat menetralkan zat toksik pada insektisida golongan organofosfat. ${ }^{20}$ Banyak hal yang dapat mempengaruhi perubahan kerentanan larva $A e$. aegypti di suatu daerah, meliputi faktor genetik, faktor bioekologi, dan faktor operasional. ${ }^{17,18}$ Faktor genetik meliputi frekuensi, jumlah dan dominasi alel resisten. Faktor bioekologi meliputi perilaku nyamuk, jumlah generasi per tahun, mobilitas dan migrasi. Faktor operasional meliputi jenis dan sifat insektisida yang digunakan, jenis insektisida yang telah digunakan sebelumnya, jangka waktu, dosis, frekuensi, cara aplikasi dan bentuk formulasi. ${ }^{13}$

Beberapa hal yang dapat menjelaskan mengapa pada ketiga kecamatan masih belum terjadi resistensi terhadap temephos ini adalah masyarakat Kecamatan Kuranji, Koto Tangah dan Padang Timur melakukan berbagai macam cara pengendalian DBD. Salah satu strategi pengendalian DBD yang diterapkan oleh Dinkes Kota Padang adalah PSN melalui program $3 \mathrm{M}$, yaitu menguras, menutup dan manfaatkan kembali tempat perkembangbiakan nyamuk. ${ }^{9}$ Selain PSN dan evaluasi rutin terhadap resistensi, salah satu upaya yang dapat dilakukan untuk mencegah resistensi Ae. aegypti adalah menghindari penggunaan yang berlebihan atau tidak sesuai aturan dari suatu larvisida dan mempertimbangkan pemakaian larvisida lain (rotasi larvisida) seperti Bacillus Thuringiensis Israelensis (Bti) yang saat ini mulai berkembang. ${ }^{3,21}$

\section{SIMPULAN}

Status kerentanan larva Ae. aegypti pada Kecamatan Kuranji telah mengalami penurunan, dibuktikan pada hasil pengolahan data ditemukan kematian larva sebanyak $86 \%$. Sedangkan larva pada Kecamatan Padang Timur dan Kecamatan Koto Tangah masih tergolong dalam status rentan dengan kematian larva pada dosis diagnostik sebanyak $99 \%$. Walaupun pada ketiga kecamatan belum termasuk kedalam golongan resisten, tetapi telah terjadi penurunan kerentanan yang ditandai dengan nilai $\mathrm{LC}_{99}$ lebih besar dari 0,02 mg/L.

\section{UCAPAN TERIMA KASIH}

Terima kasih kepada semua pihak atas sumbang sarannya, sehingga penelitian ini dapat diselesaikan sebagaimana mestinya.

\section{DAFTAR PUSTAKA}

1. World Health Organization. Dengue guidelines for diagnosis, treatment, prevention, and control. 2009 (diunduh 22 Desember 2015). Tersedia dari: URL: HYPERLINK http://www.who.int/tdr/publications/ documents/dengue-diagnosis.pdf

2. Bathia R, AP Dash, $T$ Sunyoto. Changing epidemiology of dengue in Southeast Asia. WHO South-East Asia Journal of Public Health. 2013; 2(1): 23-7.

3. Kementerian Kesehatan RI. Buletin jendela epidemiologi volume 2. 2010 (diunduh 22 Desember 2015). Tersedia dari: URL: HYPERLINK http://www.depkes.go.id/download.php?file =download/pusdatin/buletin/buletin-dbd.pdf

4. Kementerian Kesehatan RI.. Data dan informasi tahun 2014. 2015 (diunduh 23 Desember 2015). Tersedia dari: URL: HYPERLINK http://www. Depkes.go.id/resources/download/pusdatin/ profilkesehatan-indonesia/profil-kesehatan-indonesia2014.pdf

5. Dinas Kesehatan Provinsi Sumatera Barat. Profil kesehatan provinsi Sumatera Barat tahun 2012. 2012 (diunduh 21 Desember 2015). Tersedia dari: 
URL: HYPERLINK http://www.depkes.go.id/ resources/download/profil/PROFIL KES PROVIN SI 2012/03 Profil Kes Prov.SumateraBarat 2012 .pdf

6. Brooks GF. Medical Microbiology. Edisi ke-25. 2010.The McGraw-Hill Companies, Inc. New York. Terjemahan A.W Nugroho. 2012. Mikrobiologi Kedokteran. Edisi 25. EGC. Jakarta.

7. World Health Organization. Global strategy for dengue prevention and control. 2012 (diunduh 21 Desember 2015). Tersedia dari: URL: HYPERLINK http://apps.who.int/iris/bitstream/10665/75303/1/ 9789241504034 eng.pdf

8. Ridha MR, K Nisa. Larva aedes aegypti sudah toleran terhadap temephos di Kota Banjarbaru, Kalimantan Selatan. Jurnal Vektora. 2011; 3(2): 93-111.

9. Dinas Kesehatan Provinsi Sumatera Barat. Profil kesehatan Provinsi Sumatera Barat tahun 2013. 2013 (diunduh 21 Desember 2015). Tersedia dari URL : HYPERLINK https://dinkeskotapadang1. files.wordpress.com/2014/08/profil- tahun-2013edisi-2014.pdf

10. Fuadzy $H$, Hodijah DN, Jajang A, Widawati $M$. Kerentanan larva aedes aegypti terhadap temefos di tiga kelurahan endemis demam berdarah dengue Kota Sukabumi. Buletin Penelitian Kesehatan. 2015; 43(1): 41-6.

11. Setiawan YD, Z Fikri Z. Efektifitas larvisida temephos (abate 1G) terhadap nyamuk aedes aegypti Kecamatan Sewon Kabupaten Bantul DIY tahun 2013. Media Bina IImiah. 2014;8(4):33-6.

12. World Health Organization. Instruction for determining the susceptibility or resistance of mosquito larvae to insecticides. 1981 (diunduh 26 Desember 2015). Tersedia dari: URL: HYPERLINK http://apps.who.int/iris/bitstream/10665/69615/1/W HO VBC 81.807 eng.pdf

13. Istiana, F Heriyanti, Isnaini. Status kerentana larva aedes aegypti terhadap temefos di Banjarmasin Barat. Jurnal Buski. 2012;4(2):53-8.
14. Mulyanto KC, A Yamanaka, Ngandino, E Konishi. Resistance of aedes aegypti (L.) larvae to temephos in Surabaya, Indonesia. Southeast Asian J Trop Med Public Health. 2012; 43(1):29-33.

15. Carvalho MDSL, ED Caldas, N Degallier, PTR Vilarinhos, LCKR de Souza, MAC Yoshizawa, et al. Susceptibility of Aedes aegypti larvae to the insecticide temephos in the Federal District, Brazil. Rev Saúde Pública. 2004; 38(5):1-6.

16. Uthai UL, P Rattanapreechachai, L Chowanadisai. Bioassay and effective concentration of temephos against Aedes aegypti larvae and the adverse effect upon indigenous predators: toxorhynchites splendens and microneta sp. Asia Journal of Public Health. 2011; 2(2):67-77.

17. Insecticide Resistance Action Committee. Prevention and management of resistance in vectors of public health importance $2^{\text {nd }}$ edition. 2011 (diunduh 24 Desember 2015). Tersedia dari: URL: HYPERLINK http://www.irac-online.org /content /uploads /VM-Layout-v2.6 LR.pdf

18. Food and Agriculture Organization of United Nation. Guideline on prevention and management of pesticide resistance. 2012 (diunduh 23 Desember 2015). Tersedia dari: URL: HYPERLINK http://www.eppo.int/PPPRODUCTS/resistance/ FAO RMG Sept 12.pdf

19. Brogdon WG, JC McAllister. Insecticide resistance and vector control. Emerging Infectious Disease. 1998; 4(4):605-13.

20. Hemingway J, H Ranson. Insecticide resistance in insect vector of human disease. Annual Review of Entomology. 2000;45:371-91.

21. World Health Organization. Comprehensive guidelines for prevention and control of dengue and dengue haemorrhagic fever. 2011 (diunduh 21 Desember 2015). Tersedia dari: URL: HYPERLINK http://apps.searo.who.int/pds docs/B4751.pdf 